\title{
Analisis Faktor - Faktor yang Mempengaruhi Akuntabilitas Pengelolaan Dana Desa di Kabupaten Lombok Tengah
}

\author{
Baiq Mira Luthfiani ${ }^{1}$ \\ Fakultas Ekonomi dan Bisnis \\ Universitas Mataram, Indonesia \\ Email: cahyasuryani13@yahoo.com
}

\author{
Thatok Asmony ${ }^{2}$ \\ Fakultas Ekonomi dan Bisnis \\ Universitas Mataram, Indonesia
}

\section{Rr Titiek Herwanti ${ }^{2}$ \\ Fakultas Ekonomi dan Bisnis \\ Universitas Mataram, Indonesia}

\begin{abstract}
ABSTRAK
Akuntabilitas pengelolaan dana desa merupakan pertanggungjawaban pemerintah desa pada masyarakat terkait pengelolaan dana desa. Penelitian ini bertujuan memperoleh bukti empiris pengaruh kompetensi perangkat desa, aplikasi siskeudes, kepatuhan pajak bendaharawan desa dan partisipasi masyarakat pada akuntabilitas pengelolaan dana desa. Metode dalam penelitian ini adalah kuantitatif deskriptif dengan teknik analisis data menggunakan uji regresi linear berganda. Penelitian dilaksanakan di 127 pada 12 Kecamatan Kabupaten Lombok Tengah. Sampel dalam penelitian ini sebanyak 88 orang yang ditentukan menggunakan metode purposive sampling. Data dikumpulkan dengan metode kuesioner. Hasil penelitian menunjukkan kompetensi perangkat desa dan patisipasi masyarakat tidak berpengaruh terhadap akuntabilitas pengelolaan dana desa, sedangkan aplikasi siskeudes dan kepatuhan pajak bendaharawan desa berpengaruh positif pada akuntabilitas pengelolaan dana desa.
\end{abstract}

Kata Kunci: Akuntabilitas; Kompetensi Perangkat; Aplikasi Siskeudes; Kepatuhan Pajak; Partisipasi Masyarakat.

\section{Analysis of Factors Affecting Accountability in Village Fund Management in Central Lombok District}

\begin{abstract}
Accountability of village fund management is the responsibility of the village government to the community related to village fund management. This study aims to obtain empirical evidence of the influence of the competence of village officials, the application of the social security system, the tax treasurer compliance of the village treasury and community participation in the accountability of village fund management. The method in this research is descrip tive quantitative with data analysis techniques using multiple linear regression test. The study was conducted in 127 in 12 districts of Central Lombok Regency. The samples in this study were 88 people who were determined using the purposive sampling method. Data collected by questionnaire method. The results showed the competence of village officials and community participation did not affect the accountability of village fund management, while the application of the siskeudes and tax treasury compliance of the village treasurer had a positive effect on the accountability of village fund management.
\end{abstract}

Keywords: Accountability; Device Competency; Siskeudes Application; Tax Compliance; Society Participation.

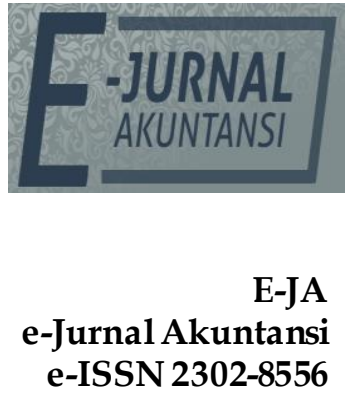

Vol. 30 No. 7

Denpasar, Juli 2020

Hal.1886-1899

Artikel Masuk:

29 April 2020

Tanggal Diterima: 10 Juli 2020

The Article is Available in: https://ojs.unud.ac.id/index.php/Akuntansi/index 


\section{PENDAHULUAN}

Desa merupakan representasi dari kesatuan masyarakat hukum terkecil yang telah ada dan tumbuh berkembang seiring dengan sejarah kehidupan masyarakat Indonesia dan menjadi bagian yang tidak terpisahkan dari tatanan kehidupan bangsa Indonesia ( DJPK, 2017). Sebagai wujud pengakuan negara terhadap desa, diperlukan kebijakan penataan dan pengaturan mengenai desa yang diwujudkan dengan lahirnya Undang- Undang Nomor 6 Tahun 2014 tentang Desa (DJPK, 2017).

Presiden Republik Indonesia secara khusus memberikan perhatian terhadap pembangunan dan pemberdayaan masyarakat desa sehingga saat ini melalui program nawacita berkomitmen untuk membangun Indonesia dari pinggiran dengan memperkuat daerah- daerah dan desa dalam kerangka Negara Kesatuan Republik Indonesia dengan mengusung konsep swakelola (DJPK, 2017). Dalam menjalankan roda pemerintahan desa, diperlukan dana yang tidak sedikit, salah satu sumber pembiayaan belanja desa adalah Dana Desa. Adapun Dana Desa adalah dana yang bersumber dari Anggaran Pendapatan dan Belanja Negara yang diperuntukkan bagi desa yang ditransfer melalui Anggaran Pendapatan dan Belanja Daerah Kabupaten/kota dan digunakan untuk membiayai penyelenggaran pemerintahan, pelaksanaan pembangunan, dan pemberdayaan masyarakat.

Adapun fenomena sektor publik yang terjadi dalam pengelolaan dana desa adalah tingginya tuntutan mengenai akuntabilitas pengelolaan dana desa yang harus menjadi prioritas utama pemerintah desa. Karena akuntabilitas menunjuk pada suksesnya pemberian informasi dan pengungkapan publik atas aktivitas dan kinerja keuangan Pemerintah Desa dalam mencapai visi dan misi Undangundang desa yaitu terciptanya desa yang maju, mandiri, sejahtera, demokratis dan berkeadilan, serta mampu untuk mengatur atau mengurus diri sendiri dalam upaya mencapai kemajuan pembangunan infrastruktur dan pemberdayaan masyarakat di desa. Akuntabilitas atau pertanggung jawaban adalah suatu bentuk keharusan seseorang agar semua tugas dan kewajiban yang diberikan dapat dilaksanakan sesuai ketentuan yang berlaku (Suwarjeni, 2015). Akuntabilitas terbagi kedalam tiga jenis yaitu akuntabilitas keuangan, akuntabilitas manfaat, dan akuntabilitas prosedural (LAN \& BPKP,2000). Mada et al. (2017) menyebutkan faktor- faktor yang mempengaruhi akuntabilitas pengelolaan keuangan desa meliputi komitmen organisasi, kompetensi aparat, partisipasi masyarakat, selanjutnya Gayatri et al. (2019) menambahkan variabel kepemimpinan kepala desa sebagai faktor yang mempengaruhi akuntabilitas.

Kabupaten Lombok Tengah menerima penyaluran dana desa sejak tahun 2015 sampai dengan tahun 2018 dengan jumlah yang meningkat setiap tahunnya. Jumlah Dana Desa yang dialokasikan oleh Pemerintah Pusat kepada Kabupaten Lombok Tengah pada Tahun 2015 sebesar 41.362.392.000,- dan terus meningkat sampai sebesar 155.444.598.000,- pada Tahun 2018. Adapun jumlah dana desa yang meningkat setiap tahun, harus selaras dengan peningkatan kemampuan dan kompetensi perangkat desa untuk melaksanakan pengelolaan keuangan desa, yang meliputi perencanaan, pelaksanaan, penatausahaan, pelaporan dan pertanggungjwaban keuangan, hal tersebut tak lain agar dicapainya akuntabilitas 
pengelolaan dana desa yang akan berdampak langsung terhadap tata kelola pemerintahan desa yang baik (Permendagri 113 tahun 2014).

Dalam Laporan Hasil Pemeriksaan Atas Laporan Keuangan Pemerintah Kabupaten Lombok Tengah untuk tahun anggaran 2018, tentang Laporan Hasil Pemeriksaan Atas Kepatuhan Terhadap Peraturan Perundang- Undangan Nomor 129.C/LHP-LKPD/XIX.MTR/05/2019 tanggal 24 Mei 2019, diungkapkan bahwa terdapat indikasi kerugian daerah pada Pemerintah Desa Beraim senilai 585.576.534,- atas empat temuan penyalahgunaan Dana Desa, berupa pekerjaan fisik, pengeluaran operasional, pelaporan yang tidak akuntabel dan pembiayaan BUMDes. Selanjutnya diungkapkan juga pengelolaan APB Desa Jago tidak sesuai dengan ketentuan yang berakibat pada beberapa kegiatan fisik berupa pembangunan rabat dan pembangunan talud yang dibiayai dana desa belum selesai dilaksanakan, keterlambatan tersebut berdampak langsung terhadap terlambatnya pemanfaatan infrastruktur oleh masyarakat desa dan berakibat pula pada kekurangan penyetoran pajak pusat (PPN dan PPh) sebesar 31.879.032,-. Diungkapkan juga terdapat beberapa desa di Kabupaten Lombok Tengah yang memiliki catatan atas kekurangan penyetoran pajak pusat (PPN dan PPh) pada KPP Pratama Praya, akibat bendaharawan desa belum menyetorkan pembayaran pajak pada Tahun Anggaran 2018 sebesar 369.422.932,- dan belum melakukan penginputan pajak dengan benar pada aplikasi siskeudes, sehingga terdapat selisih pengakuan jumlah pajak yang dibayarkan dengan jumlah pajak yang tercatat pada KPP Pratama Praya sehingga mengakibatkan kerugian negara sebesar 265.471.423,- (BPK RI, 2019).

Dalam hal kompetensi perangkat desa Rudana (2005:6) menjelaskan bahwa kompetensi merujuk kepada pengetahuan (knowledge), keahlian (skills) dan kemampuan (abilities), yang dapat didemonstrasikan yang dilakukan dengan standar tertentu. Kompetensi dapat diobservasi, merupakan tindakan perilaku yang memerlukan kombinasi dari ketiga hal ini. Mada et al. (2017) mengungkapkan rendahnya kompetensi sumber daya manusia aparat pemerintah desa merupakan faktor penghambat terwujudnya akuntabilitas pengelolaan keuangan desa. Penelitian sebelumnya terkait pengaruh kompetensi perangkat desa juga dilaksanakan oleh Rulyanti et al. (2017), Munti et al. (2017), dengan hasil penelitian kompetensi perangkat desa berpengaruh terhadap akuntabilitas pengelolaan keuangan desa namun hasil berbeda diungkapkan Widyatama et al. (2017) dimana kompetensi aparatur tidak berpengaruh signifikan terhadap Akuntabilitas dalam Pengelolaan Alokasi Dana Desa.

Selanjutnya untuk mendukung kegiatan pengelolaan kas desa yang cukup besar pemerintah khususnya pihak BPKP membuat sebuah aplikasi yang bertujuan untuk meningkatkan kualitas tata kelola keungan desa. Aplikasi yang dimaksud adalah Aplikasi Sistem Keuangan Desa (Siskeudes). Pengembangan aplikasi Siskeudes sudah dipersiapkan sejak awal dalam rangka mengantisipasi penerapan UU Nomor 6 Tahun 2014 tentang Desa. Penelitian tentang penggunaan Aplikasi Siskeudes dalam penatausahaan keuangan desa dilakukan oleh Suharman dan Lusiono (2017), Juardi et al. (2018) dan Nintyari et al. (2019) yang menyatakan penggunaan sistem informasi yaitu aplikasi siskeudes sangat berdampak baik terhadap pelaksanaan pengeloaan keuangan desa, disebabkan 
karena Aplikasi Siskeudes relatif mudah digunakan dan mengakomodir kebutuhan pentausahaan keuangan desa.

Adapun tujuan disalurkannya dana desa oleh Pemerintah Pusat adalah untuk pembangunan dan pemberdayaan masyarakat desa. Kegiatan pembangunan infrastruktur desa yang dibiayai dana desa akan menimbulkan beban pajak berupa pajak penghasilan dan pajak pertambahan nilai. Kontribusi pajak bagi pembangunan Indonesia memiliki peran yang signifikan, yaitu sebagai sumber penerimaan terbesar negara. Salah satu kontribusi pajak adalah membiayai pengeluaran Pemerintah Pusat berupa dana transfer ke daerah dan dana desa. Dana transfer ke daerah dan dana desa ini selanjutnya dipergunakan untuk membiayai pembangunan fisik dan non fisik di daerah sampai ke desa. Melihat peran dan kontribusi pajak begitu penting bagi pembangunan Indonesia maka wajar Pemerintah dalam hal ini Direktorat Jendral Pajak (DJP) terus berupaya untuk mengoptimalkan penerimaan tersebut. Fadhil dan Subandi (2018) mengungkapkan berbagai upaya dalam peningkatan penerimaan pajak mulai dari reformasi sistem administrasi perpajakan, peningkatan kepatuhan pajak hingga peningkatan kualitas layanan. Adapun penelitian terdahulu, yang juga membahas terkait kepatuhan perpajakan Bendaharawan Desa sebagai variable dependent, adalah Marsus et al. (2019) dan Wafirotin (2019), sedangkan Kepatuhan Pajak Bendaharawan sebagai variabel independen menjadi kebaruan dalam penelitian ini.

Mada et al. (2017) juga mengungkapkan akuntabilitas dapat diperkuat dengan partisipasi masyarakat. Partisipasi masyarakat menurut Isbandi (2007:27) adalah keikutsertaan masyarakat dalam proses pengidentifikasian masalah dan potensi yang ada di masyarakat, pemilihan dan pengambilan keputusan tentang alternatif solusi untuk menangani masalah, pelaksanaan upaya mengatasi masalah, dan keterlibatan masyarakat dalam proses mengevaluasi perubahan yang terjadi. Adapun peneliti yang menguji pengaruh partisipasi masyarakat terhadap akuntabilitas pengelolaan keuangan desa diantaranya Kartika (2012), Kurrahman (2015), Widarnawati (2018) dan menyatakan bahwa akuntabilitas pengelolaan keuangan yang baik sangat ditentukan oleh partisipasi masyarakat yang tinggi. Hasil penelitian tersebut tidak sejalan dengan penelitian Syamsi (2014) yang mengungkapkan partisipasi masyarakat dalam pengelolaan anggaran dana desa masih lemah baik dari segi pikiran, tenaga, keahlian dan waktu. Penelitian selanjutnya terkait pengaruh partisipasi masyarakat terhadap akuntabilitas pengelolaan keuangan desa juga dilakukan Gayatri et al. (2019) yang menyatakan bahwa akuntabilitas pengelolaan keuangan yang baik sangat ditentukan oleh partisipasi masyarakat yang tinggi.

Adapun tujuan dilaksanakan penelitian ini adalah untuk mengetahui pengaruh faktor-faktor yaitu kompetensi perangkat desa, penggunaan aplikasi siskeudes, kepatuhan pajak bendaharawan desa dan partisipasi masyarakat terhadap akuntabilitas pengelolaan dana desa di Kabupaten Lombok Tengah. Penelitian ini didasari oleh Agency Theory dimana dalam pengelolaan dana desa pemerintah desa sebagai agen melaksanakan tugas yang diberikan oleh masyarakat desa sebagai principal yaitu untuk mencapai pengelolaan dana desa yang akuntabel. Penelitian ini juga didasari oleh Stewardship Theory yang menggambarkan bahwa tidak ada keadaan atau situasi manajemen yang 
termotivasi untuk tujuan- tujuan individu melainkan lebih fokus untuk tujuan atau sasaran utama yaitu kepentingan organisasi.

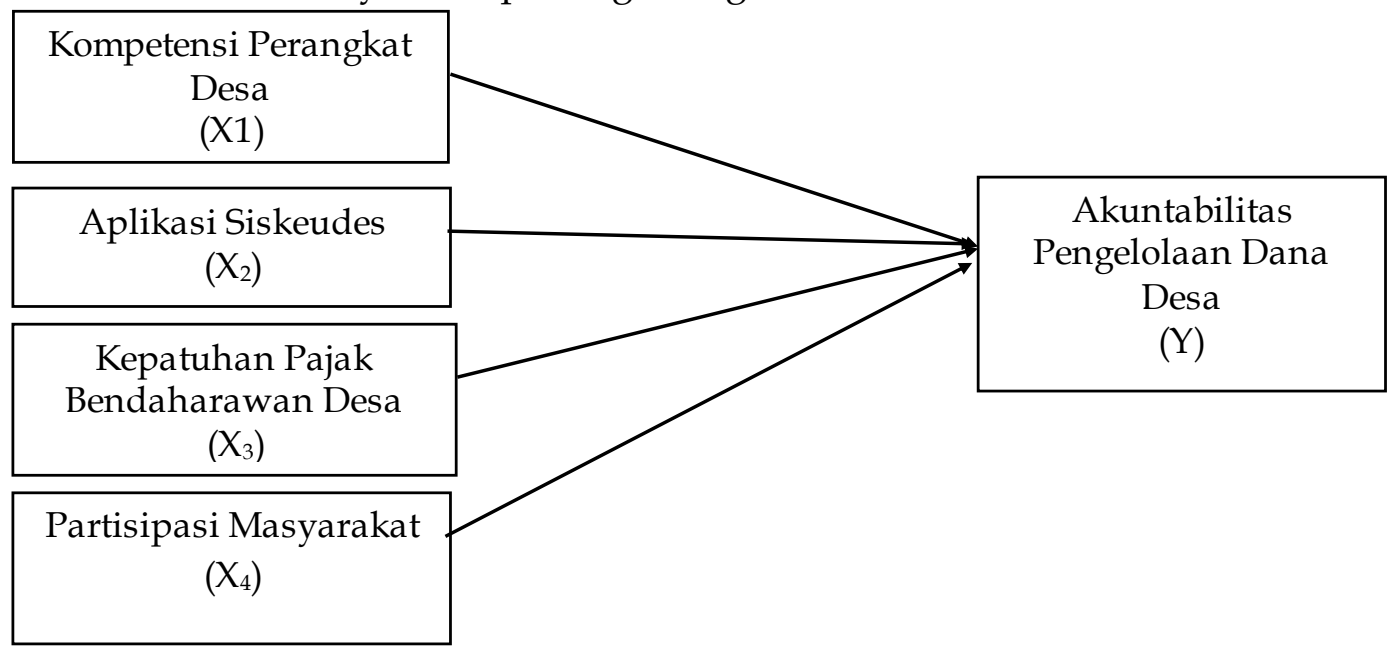

Sumber: Data Penelitian, 2020

\section{Gambar 1. Model Penelitian}

Dari Gambar 1. dapat dijelaskan penelitian ini untuk menguji pengaruh empat variabel yaitu kompetensi perangkat desa $\left(X_{1}\right)$, aplikasi siskeudes $\left(X_{2}\right)$, kepatuhan pajak bendaharawan desa $\left(X_{3}\right)$, dan partisipasi masyarakat $\left(X_{4}\right)$ terhadap variabel Akuntabilitas Pengelolaan Dana Desa (Y). Hipotesis merupakan dugaan sementara yang perlu diuji kebenarannya melalui uji statistik (Sugiyono, 2014). Jensen dan Meckling (1976) menyatakan hubungan keagenan di dalam agency theory bahwa perusahaan merupakan kumpulan kontrak antara pemilik sumber daya ekonomis (prinsipal) dan manajer (agen) yang mengurus penggunaan dan pengendalian sumber daya tersebut. Dalam hal pemerintahan desa, masyarakat desa sebagai principal menyerahkan kewengan pengelolaan keuangan desa kepada pemerintah desa sebagai agen, dan menuntut agen memiliki kompetensi sehingga dapat melaksanakan pengelolaan dana desa secara akuntabel. Gayatri et al. (2019) yang menganalisis faktor-faktor yang mempengaruhi Akuntabilitas Pengelolaan Dana Desa mengungkapkan bahwa kompetensi perangkat desa berpengaruh secara positif dan signifikan terhadap akuntabilitas pengelolaan dana desa, berdasarkan diskripsi tersebut dapat ditarik hipotesis:

$\mathrm{H}_{1}$ : Kompetensi perangkat desa berpengaruh positif terhadap terwujudnya akuntabilitas pengelolaan dana desa di Kabupaten Lombok Tengah.

Selanjutnya dalam pengelolaan dana desa yang tidak sedikit Pemerintah desa sebagai agen membutuhkan alat bantu berupa sistem informasi yang dapat mempermudah kinerja dalam pengelolaan dana desa. Sistem informasi dapat diartikan sebagai suatu pengorganisasian peralatan untuk mengumpulkan, menginput, memproses, menyimpan, mengatur, mengontrol dan melaporkan informasi untuk pencapaian tujuan organisasi. Untuk itu Pemerintah melalui BPKP membuat aplikasi yang dapat membantu pengelolaan dana desa yaitu aplikasi siskeudes. Juardi et al. (2018) mengungkapkan bahwa pemanfaatan aplikasi siskeudes dapat meningkatkan akuntabilitas pengelolaan keuangan desa. Bedasarkan diskripsi tersebut dapat ditarik hipotesis: 
$\mathrm{H}_{2}$ : Aplikasi siskeudes berpengaruh positif terhadap terwujudnya akuntabilitas pengelolaan dana desa di Kabupaten Lombok Tengah.

Adapun peran pajak yang merupakan sumber penerimaan terbesar negara, menuntut pemerintah melalui Dirjen Pajak berupaya untuk mengintensifkan penerimaan pajak salah satunya dengan meningkatkan kepatuhan pajak melalui sosialisasi dan pelatihan. Adapun kepatuhan pajak dapat diartikan sebagai kesadaran wajib pajak dalam melaksanakan kewajiban perpajakannya sesuai peraturan perundang- undangan perpajakan, yang meliputi wajib pajak membayar pajak dengan tepat waktu, tepat jumlah dan tepat tanggungan pajak (Subarkah dan Dewi, 2017). Dalam pengelolaan dana desa, bendaharawan desa merupakan pelaksana pemotongan, penyetoran dan pelaporan pajak. Pengaruh kepatuhan Bendaharawan Desa sebagai variable independent atau variabel yang berpengaruh terhadap akuntabilitas dana desa menjadi kebaruan dari penelitian ini. Penelitian sebelumnya lebih kepada kepatuhan pajak sebagai variable dependent atau dipengaruhi, diantaranya Subandhi dan Fadhil (2018) yang menganalisis faktor- faktor yang mempengaruhi kepatuhan wajib pajak. Kepatuhan pajak bendaharawan desa berdasar kepada stewardship theory yang merupakan salah satu cabang psikologi dan sosiologi dan didesain untuk menguji kondisi dimana eksekutif sebagai pengelola yang termotivasi untuk melakukan yang terbaik terhadap kepentingan utama organisasi. Sehingga dapat ditarik hipotesis :

$\mathrm{H}_{3}$ : Kepatuhan Pajak Bendaharawan Desa memiliki pengaruh yang positif terhadap terwujudnya akuntabilitas pengelolaan dana desa di Kabupaten Lombok Tengah.

Partisipasi masyarakat dalam penelitian ini adalah pendapat responden atas keterlibatan dan atau keikutsertaan masyarakat secara sadar dalam proses pembangunan dalam rangka mencapai suatu kondisi yang lebih baik dari sebelumnya. Berdasarkan agency theory dimana masyarakat sebagai principal memberikan kepercayaan kepada pemerintah sebagai agen dalam pengelolaan keuangan desa. Widarnawati (2018) menyatakan bahwa akuntabilitas pengelolaan keuangan yang baik sangat ditentukan oleh partisipasi masyarakat yang tinggi. Dari diskripsi ini dapat ditarik hipotesis :

$\mathrm{H}_{4} \quad$ : Partisipasi masyarakat memiliki pengaruh postif terhadap terwujudnya akuntabilitas pengelolaan dana desa di Kabupaten Lombok Tengah.

\section{METODE PENELITIAN}

Penelitian dilakukan pada pemerintahan desa di Kabupaten Lombok Tengah. Penelitian ini adalah penelitian kuantitatif deskriptif. Jenis penelitian ini adalah penelitian eksplanatori (explanatory research). Penelitian eksplanatori bertujuan untuk menjelaskan hubungan antara dua variabel atau lebih gejala atau variabel. Pertimbangan jenis tersebut adalah untuk menganalisis hubungan kausalitas (causality relationship) antara faktor- faktor yang mempengaruhi akuntabilitas pengelolaan dana desa di Kabupaten Lombok Tengah. Adapun variabel bebas atau independen dalam penelitian ini adalah kompetensi perangkat desa $\left(\mathrm{X}_{1}\right)$, aplikasi siskeudes $\left(X_{2}\right)$, kepatuhan pajak bendaharawan desa $\left(X_{3}\right)$ dan partisipasi masyarakat $\left(\mathrm{X}_{4}\right)$ sedangkan variabel terikat atau dependen adalah Akuntabilitas pengelolaan dana desa $(\mathrm{Y})$. 
Populasi dalam penelitian ini adalah perangkat desa di seluruh Desa seKabupaten Lombok Tengah sebanyak 762 orang dan sampel yang digunakan sebanyak 88 orang yang ditentukan menggunakan metode non-probability sampling sampling yaitu teknik purposive sampling. Kriteria pemilihan sampel dalam penelitian ini sesuai Peraturan Menteri Dalam Negeri Nomor 113 Tahun 2014 tentang pengelolaan keuangan desa adalah pihak yang terlibat langsung dalam pengelolaan keuangan desa yang terdiri dari Kepala Desa, Sekretaris Desa, Bendaharawan Desa, Kepala Seksi Pemerintahan, Kepala Seksi Kejahteraan, dan Badan Permusyawaratan Desa (BPD). Adapun data penelitian ini data primer diperoleh dengan bantuan instrumen kuisioner dan diukur dengan analisis regresi linear berganda menggunakan program SPSS 16.0 yang dijalankan dengan komputer.

Adapun perumusan dari regresi linear berganda dari penelitian ini sebagai berikut:

$\mathrm{Y}=\alpha+\beta_{1} X_{1}+\beta_{2} X_{2}+\beta_{3} X_{3}+\beta_{4} X_{4}+\varepsilon$

Keterangan:

\begin{tabular}{|c|c|}
\hline & $=$ Akuntabilitas pengelolaan dana desa \\
\hline a & $=$ Konstanta \\
\hline$\beta 1-\beta 4$ & $=$ Koefisien Regresi \\
\hline$X_{1}$ & $=$ Kompetensi perangkat desa \\
\hline $\mathrm{X}_{2}$ & $=$ Penggunaan Aplikasi Siskeudes \\
\hline$X_{3}$ & = Kepatuhan Perpajakan Bendaharawan Desa \\
\hline $\mathrm{X}$ & = Partisipasi masyarakat \\
\hline & $=$ Variabel gangguan/kesalahan (disturbance/error terms) \\
\hline
\end{tabular}

\section{HASIL DAN PEMBAHASAN}

Responden dalam penelitian ini adalah penyelenggara pemerintahan desa di Kabupaten Lombok Tengah, diantaranya Kepala Desa, Sekretaris Desa, Bendaharawan Desa, Kepala Seksi Pemerintahan, Kepala Seksi Perencanaan dan ketua BPD. Ringkasan pengiriman serta pengembalian kuesioner disajikan dalam Tabel 1, Berikut :

Tabel 1. Distribusi dan pengembalian kuisioner

\begin{tabular}{llll}
\hline No & Keterangan & $\begin{array}{l}\text { Kuisioeryang } \\
\text { disebar }\end{array}$ & $\begin{array}{l}\text { Kuisioner Yang } \\
\text { Kembali }\end{array}$ \\
\hline 1 & Kepala Desa & 15 & 15 \\
2 & Sekretaris Desa & 15 & 15 \\
3 & Bendaharawan Desa & 15 & 15 \\
4 & Kepala Seksi Pemerintahan & 14 & 14 \\
5 & Kepala Seksi Perencanaan & 14 & 14 \\
6 & Ketua BPD & 15 & 15 \\
& Total & 88 & 88 \\
\hline
\end{tabular}

Sumber: Data Penelitian, 2020

Validitas menurut Sugiyono (2017:125) menunjukan derajat ketepatan antara data yang sesungguhnya terjadi pada objek dengan data yang dikumpulkan oleh peneliti. Suatu instrumen dikatakan valid apabila nilai $\mathrm{r}$ pearson correlation lebih tinggi dari $\mathrm{r}$ tabel yaitu 0,2072. Hasil uji validitas menunjukkan nilai pearson correlation untuk instrumen kompentensi perangkat 
desa $\left(X_{1}\right)$ sebesar 0,6208 , instrumen aplikasi siskeudes $\left(X_{2}\right)$ sebesar 0,7728, instrumen kepatuhan pajak bendaharawan desa $\left(X_{3}\right)$ sebesar 0,634 , instrumen partisipasi masyarakat sebesar 0,6251 dan instrumen akuntabilitas pengelolaan dana desa sebesar 0,7216 . Nilai $\mathrm{r}$ pearson correlation seluruh instrumen untuk variabel dependen dan independen $>$ dari $\mathrm{r}$ tabel, yang berarti seluruh instrumen dikatakan Valid.

Menurut Ghozali (2016: 47) uji reliabilitas adalah alat untuk mengukur suatu kuesioner yang merupakan indikator dari variabel. Suatu kuesioner dikatakan reliabel atau handal adalah jika jawaban seseorang terhadap pertanyaan adalah konsisten atau stabil dari waktu ke waktu. Pengukuran reliabilitas dilakukan dengan alat bantu SPSS uji statistic Cronbach Alpha (a).

Instrumen yang reliabel adalah instrumen yang bila digunakan beberapa kali untuk mengukur suatu objek yang sama, akan menghasilkan data yang sama (Sugiyono, 2014:173). Secara matematik Suatu konstruk atau variabel dikatakan reliabel jika nilai cronbach's alpha $>0,6$. Hasil uji reliabilitas menunjukkan nilai cronbach's alpha untuk instrumen kompetensi perangkat desa $\left(X_{1}\right)$ sebesar 0,898 , instrumen aplikasi siskeudes $\left(X_{2}\right)$ sebesar 0,877 , instrumen kepatuhan pajak bendaharawan desa $\left(X_{3}\right)$ sebesar 0,891 , instrumen partisipasi masyarakat $\left(X_{4}\right)$ sebesar 0,885 dan instrumen akuntabilitas pengelolaan dana desa (Y) sebesar 0,896. Keseluruhan nilai cronbach's alpha dari instrumen penelitian $>0,6$ sehingga dapat dikatakan reliabel.

Pengujian asumsi klasik bertujuan untuk memberikan kepastian bahwa persamaan regresi yang didapatkan memiliki ketepatan dalam estimasi, tidak bias dan konsisten. Menurut Ghozali (2016:160) uji normalitas bertujuan untuk menguji apakah dalam model regresi, variabel pengganggu atau residual memiliki distribusi normal. Pendeteksian normalitas secara statistik adalah dengan menggunakan uji kolmogrov-smirnov. Uji kolmogrov-smirnov merupakan uji normalitas yang umum digunakan karena dinilai lebih sederhana dan tidak menimbulkan perbedaan persepsi. Uji kolmogrov-smirnov dilakukan dengan tingkat signifikan 0,05. Hasil pengujian statistik menunjukkan bahwa nilai signifikansi Asymp. Sig. (2-tailed) sebesar 0,152 lebih dari 0,05. Hal ini menunjukkan bahwa model regresi berdistribusi normal.

Selanjutnya uji multikoliniearitas bertujuan untuk menguji apakah pada model regresi ditemukan adanya korelasi antar variabel bebas. Adanya multikolinieritas dapat dilihat dari nilai tolerance atau Variance Inflation Factor (VIF). Apabila nilai tolerance lebih dari 0,01 atau VIF kurang dari 10, maka tidak ada multikolinieritas. Hasil pengujian multikolinieritas menghasilkan nilai tolerance untuk variabel kompetensi perangkat desa sebesar 0,387 dan nilai VIF 2,581, variabel aplikasi siskeudes nilai tolerance 0,333 dan nilai VIF 3,005, variabel kepatuhan pajak bendaharawan desa nilai tolerance 0,387 dan nilai VIF 2,581 dan nilai tolerance untuk variabel partisipasi masyarakat adalah 0,353 dan nilai VIF sebesar 2,832. Selanjutnya nilai tolerance masing-masing variabel lebih dari 0,1 dan nilai VIF kurang dari 10, sehingga dapat disimpulkan bahwa dalam model regresi tidak terjadi gejala multikolinieritas.

Uji Heteroskedastisitas bertujuan untuk menguji apakah dalam model regresi terjadi ketidaksamaan varians dari residual satu pengamatan ke pengamatan lain yang dilakukan dengan uji Glejser. Hasil uji heteroskedastisitas 
untuk variabel kompetensi perangkat desa $\left(X_{1}\right)$ nilai Sig. sebesar 0,413, variabel aplikasi siskeudes $\left(X_{2}\right)$ nilai Sig. sebesar 0,915, variabel kepatuhan pajak bendaharawan desa $\left(X_{3}\right)$ nilai Sig. sebesar 0,127 dan nilai Sig. untuk variabel partisipasi masyarkat $\left(\mathrm{X}_{4}\right)$ sebesar 0,326. Adapun nilai Sig. dari seluruh variabel independen lebih dari 0,05 yang berarti variabel-variabel tersebut tidak mengandung gejala heteroskedastisitas.

Hasil Analisis Regresi Berganda. Hasil pengujian regresi berganda adalah sebagai berikut:

$Y=-0,588+(-0,191 X 1)+0,542 X 2+0,266 X 3+0,381 X 4+\varepsilon$

Selanjutnya ingkasan hasil analisis regresi berganda dapat dilihat pada Tabel 2.

Tabel 2. Ringkasan Hasil Analisis Regresi Linier Berganda

\begin{tabular}{llll}
\hline Nama Variabel & B & T hitung & Sig \\
\hline Konstanta & 1.481 & 0.873 & 0.385 \\
Kompetensi Perangkat Desa (X1) & 0.51 & -0.409 & 0.684 \\
Aplikasi Siskeudes (X2) & 0.506 & 3.723 & 0 \\
Kepatuhan Pajak Bendaharawan Desa (X3) & 0.284 & 2.048 & 0.044 \\
PartisiPasi Masyarakat (X4) & 0.167 & 1.068 & 0.289 \\
\hline
\end{tabular}

Sumber: Data Penelitian, 2020

Nilai R square sebesar 0,609. Hal ini berarti bahwa variabel independen yakni kompetensi perangkat desa, aplikasi siskeudes, kepatuhan pajak bendaharawan desa dan partisipasi masyarakat menjelaskan 60,9\% variabel dependen yakni akuntabilitas pengelolaan dana desa. Sisanya sebesar 39,1\% dijelaskan oleh variabel lain yang tidak diteliti.

Pengaruh kompetensi perangkat desa terhadap akuntabilitas pengelolaan dana. Hasil pengujian Hipotesis pertama $\left(\mathrm{H}_{1}\right)$ yakni pengaruh kompetensi perangkat desa terhadap akuntabilitas pengelolaan dana desa menunjukkan nilai $t_{\text {hitung }}<t_{\text {tabel }}(-0.409<1,990)$. Nilai koefisien regresi sebesar 0.510. Tingkat signifikansi sebesar 0,684 ( $\mathrm{p}$ value $<0,05$ ). Hal ini menunjukkan kompetensi perangkat desa tidak berpengaruh secara signifikan terhadap akuntabilitas pengelolaan dana desa. Hasil pengujian ini tidak sesuai dengan Agency Theory (Jensen dan Meckling 1976). Agency Theory merupakan teori yang menegaskan atau menjelaskan tentang perbedaan kepentingan antara principal (pemberi amanah) dengan agen (pelaksana). Terkait dengan hubungan pemerintah desa yang bertindak sebagai agent dengan masyarakat desa sebagai principal di dalam Agency Theory untuk memastikan bahwa pengelolaan dana desa dilakukan dengan penuh kepatuhan pada berbagai peraturan dan ketentuan yang berlaku, sehingga pemanfaatannya sesuai dengan yang diamanatkan dalam Undangundang. Hasil penelitian ini selaras dengan penelitian sebelumnya oleh Widyatama et al. (2017) dimana kompetensi aparatur tidak berpengaruh signifikan terhadap Akuntabilitas dalam Pengelolaan Alokasi Dana Desa.

Pengaruh Aplikasi Siskeudes terhadap akuntabilitas pengelolaan dana desa. Hasil pengujian Hipotesis kedua $\left(\mathrm{H}_{2}\right)$ yakni pengaruh Aplikasi Siskeudes terhadap akuntabilitas pengelolaan dana desa menunjukkan nilai $t_{\text {hitung }}>t_{\text {tabel }}$ $(3,723>1,990)$. Nilai koefisien regresi sebesar 0,506 . Tingkat signifikansi sebesar 0,000 ( $\mathrm{p}$ value $<0,05$ ). Hal ini menunjukkan Aplikasi Siskeudes berpengaruh 
secara signifikan terhadap akuntabilitas pengelolaan dana desa. Hasil pengujian ini sesuai dengan Agency Theory (Jensen \& Meckling 1976). Agency Theory merupakan teori yang menegaskan atau menjelaskan tentang perbedaan kepentingan antara principal (pemberi amanah) dengan agen (pelaksana). sebagai bentuk pelaksanaan agency theory, dimana masyarakat desa sebagai principal memberikan kepercayaan kepada pemerintah desa sebagai agen. Dalam melaksanakan penatausahaan keuangan desa, agen membutuhkan alat atau sistem yang dapat mempermudah dan meningkatkan kinerja sehingga menghasilkan pengelolaan dana desa yang akuntabel. Untuk itu dengan lahirnya Aplikasi Siskeudes sebagai sistem teknologi informasi yang mudah dipahami baik oleh pemberi maupun penerima informasi keuangan, sangat membantu performa perangkat desa dalam melaksanakan pengelolaan dana desa. Hasil penelitian ini sejalan dengan hasil penelitian Suharman \& Lusiono (2017), Juardi et al. (2018) dan Nintyari et al. (2019) yang menyatakan penggunaan sistem informasi yaitu aplikasi siskeudes sangat berdampak baik terhadap pelaksanaan pengeloaan keuangan desa.

Pengaruh Kepatuhan Pajak Bendaharawan Desa terhadap akuntabilitas pengelolaan dana desa. Hasil pengujian Hipotesis ketiga $\left(\mathrm{H}_{3}\right)$ yakni pengaruh Kepatuhan Pajak Bendaharawan Desa terhadap akuntabilitas pengelolaan dana desa menunjukkan nilai $t_{\text {hitung }}>t_{\text {tabel }}(2,048>1,990)$. Nilai koefisien regresi sebesar 0,284. Tingkat signifikansi sebesar 0,044 ( $\mathrm{p}$ value $<0,05$ ). Hal ini menunjukkan Kepatuhan Pajak Bendaharawan Desa berpengaruh secara signifikan terhadap akuntabilitas pengelolaan dana desa. Hasil pengujian sesuai dengan Stewardship theory (Davis et al, 1997:24). Stewardship theory merupakan salah satu cabang psikologi dan sosiologi dan didesain untuk peneliti menguji kondisi dimana eksekutif sebagai pengelola yang termotivasi untuk melakukan yang terbaik terhadap kepentingan utama organisasi. Selanjutnya diasumsikan bahwa dengan kepatuhan perpajakan bendaharawan desa mempengaruhi terwujudnya akuntabilitas pengelolaan dana desa. Hasil penelitian terkait pengaruh kepatuhan pajak bendaharawan desa sebagai variabel independen terhadap akuntabilitas pengelolaan dana desa merupakan kebaruan dari penelitian ini, penelitian terdahulu yang dilaksanakan Fadhil \& Subandi (2018) menjadikan kepatuhan pajak sebagai variabel dependen.

Pengaruh Partisipasi Masyarakat terhadap akuntabilitas pengelolaan dana desa. Hasil pengujian Hipotesis keempat $\left(\mathrm{H}_{4}\right)$ yakni pengaruh Partisipasi Masyarakat terhadap akuntabilitas pengelolaan dana desa menunjukkan nilai $t_{\text {hitung }}<t_{\text {tabel }}(1.068<1,990)$. Nilai koefisien regresi sebesar 0,167 . Tingkat signifikansi sebesar 0,289 ( $\mathrm{p}$ value $<0,05$ ). Hal ini menunjukkan Partisipasi Masyarakat tidak berpengaruh secara signifikan terhadap akuntabilitas pengelolaan dana desa. Hasil pengujian ini tidak sesuai dengan Agency Theory (Jensen dan Meckling 1976). Terkait dengan hubungan pemerintah desa yang bertindak sebagai agent dengan masyarakat desa sebagai principal di dalam Agency Theory untuk memastikan bahwa pengelolaan dana desa dilakukan dengan penuh kepatuhan pada berbagai peraturan dan ketentuan yang berlaku, sehingga pemanfaatannya sesuai dengan yang diamanatkan dalam Undangundang. Hasil penelitian ini selaras dengan hasil penelitian terdahulu oleh Syamsi (2014) yaitu partisipasi masyarakat dalam pengelolaan anggaran dana 
desa masih lemah baik dari segi pikiran, tenaga, keahlian dan waktu. Suwandi (2015) yang meneliti tentang partisipasi masyarakat menunjukan bahwa partisiapsi masyarakat dalam pelaksanaan alokasi dana desa masih kurang.

Berdasarkan hasil penelitian dan pembahasan dapat disimpulkan bahwa:

1) Kompetensi perangkat desa tidak berpengaruh secara signifikan terhadap akuntabilitas pengelolaan dana desa di Kabupaten Lombok Tengah. Artinya semakin kompeten aparat pengelola dana desa, tidak mempengaruhi akuntabilitas pengelolaan dana desa. 2) Aplikasi Siskeudes berpengaruh positif signifikan terhadap akuntabilitas pengelolaan dana desa di Kabupaten Lombok Tengah. Artinya semakin tinggi Penerapan Aplikasi Siskeudes dalam aktivitas pengelolaan dana desa, maka pengelolaan dana desa semakin akuntabel. 3) Kepatuhan Pajak Bendaharawan Desa memiliki berpengaruh terhadap akuntabilitas pengelolaan dana desa di Kabupaten Lombok Tengah. Artinya semakin tinggi kepatuhan bendaharawan desa dalam melaksanakan kewajiban perpajakan maka pengelolaan dana desa semakin akuntabel. 4) Partisipasi masyarakat tidak berpengaruh secara signifikan terhadap akuntabilitas pengelolaan dana desa di Kabupaten Lombok Tengah. Artinya semakin tingi partisipasi masyarakat dalam pelaksanaan pengelolaan keuangan dana desa tidak berpengaruh terhadap tercapainya akuntabilitas pengelolaan dana desa.

\section{SIMPULAN}

Terwujudnya akuntabilitas dalam pengelolaan dana desa harus menjadi prioritas utama Pemerintah Desa. Untuk penelitian selanjutnya hendaknya peneliti menganalisis faktor-faktor selain kompetensi perangkat desa, aplikasi siskeudes, kepatuhan pajak bendaharawan desa dan partisipasi masyarakat, sehingga pengetahuan atas faktor yang mempengaruhi akuntabilitas pengelolaan dana desa dapat lebih luas. Selain itu cakupan wilayah penelitian sebaiknya lebih luas, supaya mendapatkan responden yang lebih beragam dan komplek.

Selanjutnya kepada pemerintah desa untuk terus meningkatkan kompetensi perangkat desa, pemanfaatan aplikasi siskeudes dengan maksimal, kepatuhan pajak bendaharawan desa dan partisipasi masyarakat untuk terus ditingkatkan, agar penerapan agency theory dan stewardship theory berupa keterbukaan informasi terkait pengelolaan dana desa yang disampaikan oleh pemerintah desa sebagai agen dapat diterima dengan baik oleh masyarakat sebagai principal, sehingga tujuan utama organisasi yaitu akuntabilitas pengelolaan dana desa dapat tercapai.

Penelitian ini menggunakan sampel yang tergolong kecil dan waktu penelitian yang terbatas dan kurangnya literatur penelitian terdahulu yang meneliti terkait akuntabilitas pengelolaan dana desa. Ruang lingkup penelitian hanya terbatas pada pemerintah desa di Kabupaten Lombok Tengah, sehingga rekomendasi penelitian tidak berlaku pada desa yang memiliki karekter budaya, letak geografis dan luas wilayah yang berbeda.

\section{REFERENSI}

Direktorat Jendral Perimbangan Keuangan. 2017. Buku Pintar Dana Desa. Kementrian Keuangan Republik Indonesia, Jakarta. 112 hal. 
Direktorat Jendral Perimbangan Keuangan. 2017. Buku Saku Dana Desa. Kementrian Keuangan Republik Indonesia, Jakarta. 98 hal.

Donaldson, L., \& Davis, J.H. 1991. Stewardship Theory or Agency Theory: CEO Governance \& Shareholder Return. Australian Jurnal of Management. The University of New South Wales.

Fadhil, M.I.I. Hendi Subandi. 2018. Analisis Faktor-Faktor yang Memengaruhi Kepatuhan Pajak Bendahara Desa Di Kota Batu. Jurnal Berkala Akuntansi dan Keuangan Indonesia. Hal 1-16.

Ferina, I. S. 2016. Tinjauan Kesiapan Pemerintah Desa dalam Implementasi Peraturan Menteri Dalam Negeri Nomor 113 tentang Pengelolaan Keuangan Desa (Studi Kasus pada Pemerintah Desa di Kabupaten Ogan Hir), Jurnal Manajemen dan Bisnis Sriwijaya. Hal.321-336.

Frink, D. D. Richard Klimoski. 2004. Advancing Accountability Theory and Practice: Intorduction to The Human Resource Management Review Special Edition. Human Resource Management Review. Page 1-17.

Gayatri, dan Komang A.J.P.D. 2019. Faktor-Faktor Yang Berpengaruh Pada Akuntabilitas Pengelolaan Dana Desa. E-Jurnal Akuntansi Universitas Udayana. Hal. 1269-1298.

Ghozali, I. 2016. Aplikasi Analisis Multivariate dengan Program IBM SPSS 23. Semarang: Badan Penerbit Universitas Diponegoro.

IAI-KSAP. 2015. Pedoman Asistensi Akuntansi Keuangan Desa. Jakarta: Ikatan Akuntan Indonesia.

Indrianasari, N.T. 2017. Peran Perangkat Desa dalam Akuntabilitas Pengelolaan Keuangan Desa (Studi Pada Desa Karangsari Kecamatan Sukodono). Jurnal Ilmiah Ilmu Akuntansi, Keuangan Dan Pajak. Hal 26-46.

Isbandi, R.A. 2007. Perencanaan Partisipatoris Berbasis Aset Komunitas: dari Pemikiran Menuju Penerapan. Depok. Fisip Universitas Indonesia.

Jensen. M.C. W.H. Meckling. 1976. Theory of the Firm: Managerial Behavior, Agency Costs and Ownership Structure. Journal of Financial Economics, 3(4), 305-36

Juardi, M.S.S. Mustakim M., Reski A.P. 2018. Evaluasi Penggunaan Aplikasi Siskeudes Dalam Upaya Peningkatan Kualitas Akuntabilitas Keuangan Desa (Studi Pada Desa Jenetallasa Kec. Pallangga Kab. Gowa). Jurnal Ilmiah Akuntansi Peradaban. Hal 84-107.

Kementrian Dalam Negeri Republik Indonesia. 2007. Peraturan Menteri Dalam Negeri Republik Indonesia Nomor 37 Tahun 2007 Tentang Pedoman Pengelolaan Keuangan Desa. Jakarta: Indonesia.

Kementrian Keuangan Republik Indonesia. 2017. Peraturan Menteri Keuangan Nomor 50 Tahun 2017.Tentang Pengelolaan Transfer Ke Daerah dan Dana Desa. Jakarta: Indonesia.

Lembaga Administrasi Negara (LAN) dan Badan Pengawas Keuangan dan Pembangunan (BPKP). 2000. Akuntabilitas dan Good Governance. Jakarta: Lembaga Administrasi Negara.

Lusiono, E.F., dan Suharman. 2017. Analisis Penerimaan Aplikasi Siskeudes Di Lingkungan Pemerintah Daerah Kabupaten Sambas. Jurnal Akuntansi, Ekonomi dan Manajemen Bisnis. Hal 163-172. 
Mardiasmo. 2006. Otonomi Daerah Dan Manajemen Keuangan Daerah. Yogyakarta: Andi Offset;

Mada, S. Lintje K. 2017. Pengaruh Kompetensi Aparat Pengelola Dana Desa, Komitmen Organisasi Pemerintah Desa, dan Partisipasi Masyarakat Terhadap Akuntabilitas Pengelolaan Dana Desa Di Kabupaten Gorontalo. Jurnal Riset Akuntansi dan Auditing. Hal 106-115.

Makalalag, A.J. 2017. Akuntabilitas Pengelolaan Dana Desa di Kecamatan Kotamobagu Selatan Kota Kotamobagu. Jurnal Riset Akuntansi dan Auditing "Goodwill". Hal 149-158.

Marsus, S., Andikha D.N.S., Ajar P.A., dan Wayan M. 2019. Pendampingan Tata Kelola Keuangan, Aset Dan Pajak Tiga Desa Di Kabupaten Bogor. Wikrama Parahita Jurnal Pengabdian Masyarakat JPM Wikrama Parahita. Hal 39-46.

Mikkelsen. B. 1999. Metode Penelitian Partisipatoris dan Upaya-upaya Pemberdayaan: Panduan Bagi Para Praktisi Lapangan. Jakarta: Yayasan Obor Indonesia.

Munti, F. dan Heru F. 2017. Determinan Kinerja Pengelolaan Keuangan Desa: Studi pada Kecamatan Gandapura Kabupaten Bireuen Aceh. Jurnal Akuntansi dan Investasi. Hal 172-182.

Nintyari, L.N. Putu S.K. Ananta W.T.A. 2019. Pengaruh Kompetensi Sumber Daya Manusia, Sosialisasi, Serta Manajemen Kontrol Terhadap Efektivitas Dan Efisiensi Pelaksanaan Sistem Keuangan Desa (Siskeudes) (Studi Empiris Pada Desa-Desa Penerima Dana Desa Di Kabupaten Tabanan). Jurnal Ilmiah Mahasiswa Akuntansi. Hal 2614 - 1930.

Pemerintah Republik Indonesia. 2014. Undang-Undang Nomor 6 Tahun 2014 tentang Desa. Jakarta: Indonesia.

Ross, M.G. 1967. Community Organization: Theory, Principles and Practice. New York : Harper and Row Publishers.

Rulyanti, D., Raden A.S., dan Yosefa S. 2017. Faktor-Faktor Yang Mempengaruhi Kinerja Pemerintah Desa Melalui Pengelolaan Keuangan Desa Sebagai Variabel Intervening. Jurnal Bisnis dan Manajemen.Hal. 323 - 335.

Saad, N. 2014. Tax Knowledge, Tax Complexity, Tax Compliance: tax Payers' View. Procedia-Social and Behavioral Sciences.109.2014. Elsevier Ltd.

Setiawan, A., Muhtar H., Nila F.W. 2017. Akuntabilitas Pengelolaan Dana Desa di Desa Budugsidorejo Kabupaten Jombang Tahun 2015. Politik Indonesia: Indonesian Political Science Review. Hal 1-16.

Sugiyono. 2014. Metode Penelitian Pendidikan-Pendekatan Kuantitatif, Kualitatif, R E D. Badung. Alfabeta Bandung.

Sugiyono. 2017. Metode Penelitian Kuantitatif, Kualitatif dan RED. Bandung. Alfabeta Bandung.

Sujarweni, W.V. 2015. Akuntansi Sektor Publik: Teori, Konsep, dan Aplikasi. Pustaka Baru: Yogyakarta.

Suwandi. 2015. Partisipasi Masyarakat Dalam Pelaksanaan Alokasi Dana Desa (ADD) Di Kantor Desa Suka Damai Kecamatan Muara Badak Kabupaten Kutai Kartanegarae. Journal Administrasi Negara. Hal 1183-1194.

Syarifudin, A. 2014. Pengaruh Kompetensi SDM dan Peran Audit Intern terhadap Kualitas Laporan Keuangan Pemerintah Daerah dengan Variabel Intervening Sistem PengendalianInternal Pemerintah (studi empiris pada Pemkab Kebumen). Jurnal Fokus Bisnis. Hal 26-44. 
Syamsi, S. 2014. Partisipasi Masyarakat dalam Mengontrol Penggunaan Anggaran Dana Desa. Jurnal Ilmu Sosial dan Ilmu Politik. Hal 21-28.

Widarnawati, B.W. 2018. Determinan Pengelolaan Keuangan Desa Dan Implikasinya Terhadap Kepercayaan Stakeholders (Studi Pada Pemerintah Desa Se - Kabupaten Lombok Tengah. Tesis. Universitas Mataram.

Widoyoko, E.P. 2014. Teknik Penyusunan Instrumen Penelitian. Yogyakarta: Pustaka Pelajar.

Widyatama, A., Lola N., Diarespati. 2017. Pengaruh Kompetensi dan Sistem Pengendalian Internal Terhadap Akuntabilitas Pemerintah Desa dalam Mengelola Alokasi Dana Desa (ADD). Jurnal Berkala Akuntansi dan Keuangan Indonesia. Hal 1-20. 